\title{
Amphiphilic Random Copolymers with Hydrophobic/Hydrogen-Bonding Urea Pendants: Self-Folding Polymers in Aqueous and Organic Media
}

\author{
Kazuma Matsumoto, ${ }^{1}$ Takaya Terashima, ${ }^{1} *$ Takanori Sugita, ${ }^{1}$ Mikihito Takenaka, ${ }^{1,2}$ \\ Mitsuo Sawamoto*1 \\ ${ }^{1}$ Department of Polymer Chemistry, Graduate School of Engineering, Kyoto University \\ Katsura, Nishikyo-ku, Kyoto 615-8510, Japan \\ ${ }^{2}$ RIKEN SPring-8 Center, Sayo-cho, Sayo-gun, Hyogo 679-5148, Japan \\ Tel/Fax: +81-75-383-2603 \\ E-mail: terashima@living.polym.kyoto-u.ac.jp, sawamoto@star.polym.kyoto-u.ac.jp
}

\section{Contents}

Experimental Sections

Supporting Data

Figure S1. Random copolymerization of PEGMA and RMA

Figure S2. SEC curves of P5, P8, P9, and P10 in DMF and $\mathrm{H}_{2} \mathrm{O}$

Figure S3. ${ }^{1} \mathrm{H}$ NMR spectra of $\mathbf{P 5}$ and $\mathbf{P 6}$ in $\mathrm{D}_{2} \mathrm{O}$ at $25{ }^{\circ} \mathrm{C}$

Figure S4. DLS intensity distribution of $\mathrm{P12}$ in water at $25^{\circ} \mathrm{C}$

Figure S5. ${ }^{1} \mathrm{H}$ NMR spectra of P5, P10, and $\mathbf{P 3}$ in $\mathrm{CDCl}_{3}$ at $25{ }^{\circ} \mathrm{C}$

Figure S6. ${ }^{1} \mathrm{H}$ NMR spectra of BPUMA with MMA or PEO in $\mathrm{CDCl}_{3}$ at $25{ }^{\circ} \mathrm{C}$

Figure S7. ${ }^{1} \mathrm{H}$ NMR spectra of $\mathbf{P 6}$ with polar compounds in $\mathrm{CDCl}_{3}$ at $25{ }^{\circ} \mathrm{C}$

Figure S8. $R_{\mathrm{g}}$ of $\mathbf{P 1 0}$ against as a function of molar mass in DMF or $\mathrm{H}_{2} \mathrm{O} \quad \mathrm{S} 11$

Figure S9. Guinier plots for the SAXS profiles of $\mathbf{P 5}$ and $\mathbf{P 9}$ in $\mathrm{H}_{2} \mathrm{O}$ 


\section{Experimental Section}

Materials. Triethylamine (TCI, purity $>99.0 \%$ ) was purified by distillation before use. 3,5Bis(trifluoromethyl)aniline (TCI, purity >97\%), 3,5-bis(trifluoromethyl)phenyl isocyanate (TCI, purity $>98 \%$ ), 2-isocyanatoethyl methacrylate (Showa Denko, purity $>97 \%$ ), phenylacetyl chloride (TCI, purity $>98 \%$ ), dibutyltin dilaurate (TCI, purity $>95 \%$ ), dry THF (Wako, dehydrated), dry $\mathrm{CH}_{2} \mathrm{Cl}_{2}$ (Wako, dehydrated), and dry diethyl ether (Wako, dehydrated) were used without further purification. Poly(ethylene glycol) methyl ether methacrylate [PEGMA: $\mathrm{CH}_{2}=\mathrm{CMeCO}_{2}\left(\mathrm{CH}_{2} \mathrm{CH}_{2} \mathrm{O}\right)_{\mathrm{n}} \mathrm{Me} ; M_{\mathrm{n}}=475 ; n=8.5$ on average] (Aldrich) was purified by column chromatography charged with an inhibitor remover (Aldrich) and degassed by triple vacuum-argon purge cycles before use. 2-Hydroxyethyl methacrylate (HEMA, Aldrich purity $>99 \%$ ) was distilled under reduced pressure before use. 2-(3-(3,5-Bis(trifluoromethyl)phenyl)ureido)ethyl methacrylate (BPUMA) and 2-(2-phenylacetoxy)ethyl methacrylate (PAEMA) were synthesized as shown below. $\mathrm{RuCp} * \mathrm{Cl}\left(\mathrm{PPh}_{3}\right)_{2}\left(\mathrm{Cp}^{*}\right.$ : pentamethylcyclopentadienyl, Aldrich, purity $\left.>97 \%\right)$ was handled in a glove box under a moisture- and oxygen-free argon atmosphere $\left(\mathrm{H}_{2} \mathrm{O}<1 \mathrm{ppm}, \mathrm{O}_{2}<1 \mathrm{ppm}\right)$. 4Dimethylamino-1-butanol (4-DMAB, TCI, purity $>98 \%$ ) was purged by argon before use. Tetralin (1,2,3,4-tetrahydronaphthalene: Kishida Chemical, purity $>98 \%$, an internal standard for ${ }^{1} \mathrm{H}$ NMR analysis) was dried overnight over calcium chloride and distilled from calcium hydride under reduced pressure before use. Toluene (solvent) was purified by passing it through a purification column (Glass Contour Solvent Systems: SG Water USA) before use. Ethanol (Wako, dehydrated) was purged by argon before use.

Characterization. Molecular weight distribution (MWD) curves, number-average molecular weight $\left(M_{\mathrm{n}}\right)$, peak top molecular weight $\left(\mathrm{M}_{\mathrm{p}}\right)$, and $M_{\mathrm{w}} / M_{\mathrm{n}}$ ratio of polymers were measured by SEC in DMF containing $10 \mathrm{mM} \mathrm{LiBr}$ at $40{ }^{\circ} \mathrm{C}$ (flow rate: $1 \mathrm{~mL} / \mathrm{min}$ ) on three linear-type polystyrene gel columns (Shodex KF-805L: exclusion limit $=4 \times 10^{6}$; particle size $=10 \mu \mathrm{m}$; pore size $=5000 \AA$; 0.8 $\mathrm{cm}$ i.d. $\mathrm{x} 30 \mathrm{~cm}$ ) that were connected to a Jasco PU-2080 precision pump, a Jasco RI-2031 refractive index detector, and a Jasco UV-2075 UV/vis detector set at $270 \mathrm{~nm}$. The columns were calibrated against 10 standard poly(MMA) samples (Polymer Laboratories, $M_{\mathrm{n}}=1000-1200000, M_{\mathrm{w}} / M_{\mathrm{n}}=1.06-$ 1.22 ) or 10 standard poly(ethylene oxide) samples (Polymer Laboratories, $M_{\mathrm{n}}=1460-737000, M_{\mathrm{w}} / M_{\mathrm{n}}$ $=1.03-1.07$ ). MWD curves and $\mathrm{M}_{\mathrm{p}}$ of polymers were measured by $\mathrm{SEC}$ in $\mathrm{H}_{2} \mathrm{O}$ at $30{ }^{\circ} \mathrm{C}$ (flow rate: $1 \mathrm{~mL} / \mathrm{min})$ on a silica gel column $\left(\mathrm{TOSOH} \mathrm{G} 4000 \mathrm{SW}_{\mathrm{XL}}\right.$ : exclusion limit $=7 \times 10^{6}$; particle size $=8$ $\mu \mathrm{m} ; 0.8 \mathrm{~cm}$ i.d. $\mathrm{x} 30 \mathrm{~cm}$ ) that was connected to the same pump and detectors as those in DMF. The column was calibrated against 10 standard poly(ethylene oxide) samples (Polymer Laboratories, $M_{\mathrm{n}}$ $\left.=1460-737000, M_{\mathrm{w}} / M_{\mathrm{n}}=1.03-1.07\right) .{ }^{1} \mathrm{H}$ NMR spectra were recorded in $\mathrm{CDCl}_{3}$, acetone- $d_{6}, \mathrm{DMF}-$ 
$d_{7}, \mathrm{CD}_{3} \mathrm{OD}$, and $\mathrm{D}_{2} \mathrm{O}$ on a JEOL JNM-ECA500 spectrometer operating at $500.16 \mathrm{MHz}$. Electorospray ionization mass spectrometry (ESI-MS) was performed on Waters Quattro micro API. Absolute weight-average molecular weight $\left(M_{\mathrm{w}}\right)$ of polymers in DMF or $\mathrm{H}_{2} \mathrm{O}$ was determined by multi-angle laser light scattering (MALLS) equipped with SEC on a Dawn HELEOS II instrument (Wyatt Technology, semiconductor laser; $\lambda=663 \mathrm{~nm}$ ). The SEC was performed in DMF containing $10 \mathrm{mM} \mathrm{LiBr}$ at $40{ }^{\circ} \mathrm{C}$ (flow rate: $1 \mathrm{~mL} / \mathrm{min}$ ) on three linear-type polystyrene gel columns (Shodex $\mathrm{KF}-805 \mathrm{~L}$ ) or in $\mathrm{H}_{2} \mathrm{O}$ at $30{ }^{\circ} \mathrm{C}$ (flow rate: $1 \mathrm{~mL} / \mathrm{min}$ ) on a silica gel column (TOSOH G4000SW $\mathrm{XL}_{\mathrm{L}}$ ), that were connected to a Jasco PU-2080 precision pump, a Jasco RI-1530 refractive index detector, and a Jasco UV-1570 UV/vis detector set at $270 \mathrm{~nm}$. Refractive index increment $(d n / d c)$ was measured in DMF at $40{ }^{\circ} \mathrm{C}$ on an Optilab DSP refractometer (Wyatt Technology: $\lambda=690 \mathrm{~nm}, \mathrm{c}<2.5$ $\mathrm{mg} / \mathrm{mL}$ ). Dynamic light scattering (DLS) was measured on Otsuka Photal ELSZ-0 equipped with a semi-conductor laser $(\lambda=658 \mathrm{~nm})$ at $25^{\circ} \mathrm{C}$. The measuring angle was $165^{\circ}$ and the data was analyzed by CONTIN method. Cloud point of the aqueous solutions of polymers was measured on UV-1800 (Shimadzu, optical path length $=1.0 \mathrm{~cm}, \lambda=670 \mathrm{~nm}$, heating/cooling rate: $1{ }^{\circ} \mathrm{C} / \mathrm{min}$, temperature range: $30-80{ }^{\circ} \mathrm{C}$ ). Transmission electron microscopy (TEM) measurements of polymers were performed on HT7700 (Hitachi) at an accelerating voltage of $100 \mathrm{kV}$. The samples were prepared by the drop cast of the aqueous solutions of polymers $(1 \mathrm{mg} / \mathrm{mL})$ on carbon coat grids and stained with phosphotungstic acid. Small-angle X-ray scattering (SAXS) experiments were performed at RIKEN beamline BL45XU in SPring-8, Japan. The X-ray wavelength, the sample to detector distance, and the detector used at BL45XU were $0.1 \mathrm{~nm}, 2500 \mathrm{~mm}$, and PILATUS 300K-W, respectively. The obtained two-dementional data were circularly averaged and corrected for background of cell and electronic noise of detector.

Monomer Synthesis. BPUMA: In $200 \mathrm{~mL}$ round-bottomed flask filled with argon, 2isocyanatoethyl methacrylate $(65 \mathrm{mmol}, 9.2 \mathrm{~mL})$ was added to the solution of 3,5bis(trifluoromethyl)aniline $(78.2 \mathrm{mmol}, 12.1 \mathrm{~mL})$ in dry THF $(60 \mathrm{~mL})$ at $0{ }^{\circ} \mathrm{C}$. After stirring at 25 ${ }^{\circ} \mathrm{C}$ for $24 \mathrm{~h}$, the mixture was evaporated to dryness. The crude product was washed by hexane $(5 \mathrm{x}$ $100 \mathrm{~mL}$ ) to give a colorless liquid (BPUMA: $12.6 \mathrm{~g}$; 50\% yield). ${ }^{1} \mathrm{H}$ NMR [500 MHz, acetone- $d_{6}$, $\left.25{ }^{\circ} \mathrm{C}, \delta=2.05\left(\mathrm{CD}_{2} \mathrm{HCOCD}_{3}\right)\right] \delta=8.66(\mathrm{~s}, 1 \mathrm{H},-\mathrm{CONHPh}), 8.15$ (s, 2H, aromatic), $7.53(\mathrm{~s}, 1 \mathrm{H}$, aromatic), 6.30 (s, $\left.1 \mathrm{H},-\mathrm{CH}_{2} \mathrm{NHCO}-\right), 6.09$ (d, $J=1.2 \mathrm{~Hz}, 1 \mathrm{H}$, olefin), 5.62 (m, 1H, olefin), 4.24 (t, $J$ $\left.=6.0 \mathrm{~Hz}, 2 \mathrm{H},-\mathrm{COOCH}_{2} \mathrm{CH}_{2}-\right), 3.57\left(\mathrm{dt}, J=5.2,5.7 \mathrm{~Hz}, 2 \mathrm{H},-\mathrm{OCH}_{2} \mathrm{CH}_{2} \mathrm{NH}-\right), 1.91$ (dd, $J=1.8,1.2$ $\left.\mathrm{Hz}, 3 \mathrm{H},=\mathrm{CCH}_{3}\right) \mathrm{ppm} .{ }^{13} \mathrm{C}$ NMR $\left[125 \mathrm{MHz}\right.$, acetone- $\left.d_{6}, 25{ }^{\circ} \mathrm{C}, \delta=206.5\left(\mathrm{CH}_{3} \mathrm{COCH}_{3}\right)\right] \delta=167.7$, 156.0, 143.7, 137.5, $132.6\left(\mathrm{q},{ }^{2} J_{\mathrm{CF}}=32.2 \mathrm{~Hz}\right), 125.9,124.7\left(\mathrm{q},{ }^{1} J_{\mathrm{CF}}=270.7 \mathrm{~Hz}\right), 118.5,115.0,64.7$, 39.9, 18.5 ppm. IR ( $\left.\mathrm{cm}^{-1}\right): 3334$ (NH stretching), 1721 (CO; ester), 1657 (CO; urea), $1565(\mathrm{NH}$ vending). ESI-MS m/z $\left([\mathrm{M}+\mathrm{Na}]^{+}\right)$calcd. for $\mathrm{C}_{15} \mathrm{H}_{14} \mathrm{~F}_{6} \mathrm{~N}_{2} \mathrm{O}_{3}+\mathrm{Na} 407.1$, found 407.1. 
PAEMA: In $100 \mathrm{~mL}$ round-bottomed flask filled with argon, phenylacetyl chloride (0.042 mmol, $5.6 \mathrm{~mL})$ was added to the solution of HEMA $(0.028 \mathrm{mmol}, 3.4 \mathrm{~mL})$ and triethylamine $(0.048 \mathrm{mmol}$, $6.7 \mathrm{~mL})$ in dry $\mathrm{CH}_{2} \mathrm{Cl}_{2}(50 \mathrm{~mL})$ at $0{ }^{\circ} \mathrm{C}$. The mixture was stirred at $25{ }^{\circ} \mathrm{C}$ for $18 \mathrm{~h}$ and was poured into distilled water $(50 \mathrm{~mL})$. The aqueous phase was separated and extracted by $\mathrm{CH}_{2} \mathrm{Cl}_{2}(50 \mathrm{~mL})$, and the $\mathrm{CH}_{2} \mathrm{Cl}_{2}$ extracts were combined with the organic layer. The combined organic phase was washed with water $(3 \times 100 \mathrm{~mL})$, the aqueous solution of $\mathrm{Na}_{2} \mathrm{CO}_{3}(100 \mathrm{~mL})$, and brine $(100 \mathrm{~mL})$, and evaporated to dryness to give a colorless liquid (PAEMA: $2.3 \mathrm{~g}$; 33\% yield). ${ }^{1} \mathrm{H}$ NMR [500 MHz, acetone- $\left.d_{6}, 25{ }^{\circ} \mathrm{C}, \delta=2.05\left(\mathrm{CD}_{2} \mathrm{HCOCD}_{3}\right)\right] \delta=7.33-7.22(\mathrm{~m}, 5 \mathrm{H}$, aromatic), 6.03 (s, 1H, olefin), $5.62\left(\mathrm{dq}, J=1.7,1.8 \mathrm{~Hz}, 1 \mathrm{H}\right.$, olefin), 4.35 (m, $\left.4 \mathrm{H},-\mathrm{COOC} \underline{\mathrm{H}}_{2} \underline{\mathrm{H}}_{2} \mathrm{OCO}-\right), 3.67$ (s, $\left.2 \mathrm{H},-\mathrm{COC} \underline{\mathrm{H}}_{2} \mathrm{C}\right)$, $1.89\left(\mathrm{dd}, J=1.8,1.2 \mathrm{~Hz}, 3 \mathrm{H},=\mathrm{CCH}_{3}\right) \mathrm{ppm} .{ }^{13} \mathrm{C}$ NMR $\left[125 \mathrm{MHz}\right.$, acetone- $d_{6}, 25{ }^{\circ} \mathrm{C}, 206.5$ $\left.\left(\mathrm{CH}_{3} \mathrm{COCH}_{3}\right)\right] \delta=172.0,167.6,137.4,135.7,130.5,129.5,128.0,126.3,63.5,63.4,41.7,18.6$ ppm. ESI-MS m/z $\left([\mathrm{M}+\mathrm{Na}]^{+}\right)$calcd. for $\mathrm{C}_{14} \mathrm{H}_{16} \mathrm{O}_{4}+\mathrm{Na} 271.1$, found 271.2.

Polymer Synthesis. The synthesis of polymers was carried out by syringe technique under argon in baked glass tubes equipped with a three-way stopcock via ruthenium-catalyzed living radical polymerization. The typical procedure for PEGMA/BPUMA (140/60) random copolymer (P5) was given: In a $30 \mathrm{~mL}$ glass tube, $\mathrm{RuCp} * \mathrm{Cl}\left(\mathrm{PPh}_{3}\right)_{2}(0.003 \mathrm{mmol}, 2.4 \mathrm{mg})$ was placed. Then, PEGMA (2.1 mmol, $0.92 \mathrm{~mL})$, a $236 \mathrm{mM}$ ethanol solution of BPUMA (0.9 mmol, $3.81 \mathrm{~mL})$, ethanol (1.03 $\mathrm{mL})$, tetralin $(0.1 \mathrm{~mL})$, a $500 \mathrm{mM}$ ethanol solution of $4 \mathrm{DMAB}(0.12 \mathrm{~mL}, 4 \mathrm{DMAB}=0.06 \mathrm{mmol})$, and a $622 \mathrm{mM}$ ethanol solution of ECPA $(0.015 \mathrm{mmol}, 0.024 \mathrm{~mL})$ were added sequentially in that order into the tube at $25{ }^{\circ} \mathrm{C}$ under argon (The total volume: $6 \mathrm{~mL}$ ). The glass tube was placed in an oil bath kept at $40{ }^{\circ} \mathrm{C}$. At predetermined intervals, the mixture was sampled with a syringe under dry argon, and the reaction was terminated by cooling the solution to $-78^{\circ} \mathrm{C}$. The monomer conversion was determined by ${ }^{1} \mathrm{H}$ NMR in $\mathrm{CDCl}_{3}$ with tetralin as an internal standard (PEGMA/BPUMA = $92 \% / 95 \%, 23 \mathrm{~h}$ ). The quenched reaction solutions were evaporated to dryness. The crude product was fractionated by preparative SEC to give P5. SEC (DMF, PMMA std.): $M_{\mathrm{n}}=76,800 \mathrm{~g} / \mathrm{mol}$; $M_{\mathrm{w}} / M_{\mathrm{n}}=1.26 . \quad d n / d c(\mathrm{DMF})=0.045$. SEC-MALLS $(\mathrm{DMF}, 0.01 \mathrm{M} \mathrm{LiBr}): M_{\mathrm{w}}=135,000 \mathrm{~g} / \mathrm{mol}$. ${ }^{1} \mathrm{H}$ NMR $\left[500 \mathrm{MHz}\right.$, acetone- $\left.d_{6}, 25{ }^{\circ} \mathrm{C}, \delta=2.05\left(\mathrm{CD}_{2} \mathrm{HCOCD}_{3}\right)\right]: \delta 8.9-8.6\left(-\mathrm{CONHC}_{6} \mathrm{H}_{4}\left(\mathrm{CF}_{3}\right)_{2}\right)$, 8.2-8.1 (aromatic), 7.6-7.5 (aromatic), 7.4-7.2 (-OCOCHPhCH$\left.{ }_{2}^{-}\right), 6.5-6.2\left(-\mathrm{CH}_{2} \mathrm{NHCO}-\right), 4.3-4.0$

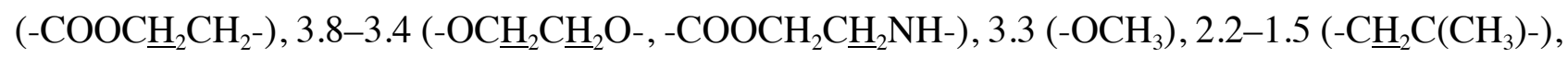
$1.3-0.8\left(-\mathrm{CH}_{2} \mathrm{C}\left(\mathrm{CH}_{3}\right)-\right) \mathrm{ppm} ; M_{\mathrm{n}}(\mathrm{NMR})=84,700 \mathrm{~g} / \mathrm{mol}$.

The other random copolymers (P1-P4, P6, P7, P9-P11) were also synthesized according to the procedure for $\mathbf{P 5}$.

PEGMA/PAEMA (140/60) random copolymer (P9). ${ }^{1} \mathrm{H}$ NMR $\left[500 \mathrm{MHz}\right.$, acetone- $d_{6}, 25{ }^{\circ} \mathrm{C}, \delta=$ $\left.2.05\left(\mathrm{CD}_{2} \mathrm{HCOCD}_{3}\right)\right]: \quad \delta$ 7.5-7.2 (aromatic), 4.4-4.3 (- $\left.\mathrm{COOCH}_{2} \underline{\mathrm{CH}}_{2} \mathrm{OCOCH}_{2}-\right)$, 4.3-4.2 (- 
$\mathrm{COOC}_{2}{ }_{2} \mathrm{CH}_{2} \mathrm{OCOCH}_{2}$ ), 4.2-4.1 (- $\left.\mathrm{COOC}_{2} \mathrm{CH}_{2} \mathrm{O}-\right)$, 3.8-3.5 (-OCOC$\left.\underline{\mathrm{H}}_{2} \mathrm{Ar},-\mathrm{OC}_{2} \underline{\mathrm{C}}_{2} \mathrm{O}-\right)$, 3.3 ($\left.\mathrm{OCH}_{3}\right), 2.2-1.5\left(-\mathrm{C}_{2} \mathrm{C}\left(\mathrm{CH}_{3}\right)-\right), 1.3-0.8\left(-\mathrm{CH}_{2} \mathrm{C}\left(\mathrm{C}_{3}\right)^{-}\right)$ppm.

PEGMA/BPOMA (140/60) random copolymer (P8). In a $30 \mathrm{~mL}$ glass tube, $\mathrm{RuCp} * \mathrm{Cl}\left(\mathrm{PPh}_{3}\right)_{2}$ (0.0050 mmol, $4.0 \mathrm{mg}$ ) was placed. Then, PEGMA (3.5 mmol, $1.5 \mathrm{~mL})$, HEMA (1.5 mmol, 0.18 $\mathrm{mL})$, ethanol $(7.1 \mathrm{~mL})$, tetralin $(0.2 \mathrm{~mL})$, a $500 \mathrm{mM}$ ethanol solution of 4DMAB (0.2 mL, 4DMAB $=0.1 \mathrm{mmol})$, and a $32 \mathrm{mM}$ ethanol solution of ECPA $(0.025 \mathrm{mmol}, 0.78 \mathrm{~mL})$ were added sequentially in that order into the tube at $25^{\circ} \mathrm{C}$ under argon (The total volume: $10 \mathrm{~mL}$ ). The glass tube was placed in an oil bath kept at $40{ }^{\circ} \mathrm{C}$. At predetermined intervals, the mixture was sampled with a syringe under dry argon, and the reaction was terminated by cooling the solution to $-78{ }^{\circ} \mathrm{C}$. The monomer conversion was determined by ${ }^{1} \mathrm{H}$ NMR in $\mathrm{CDCl}_{3}$ with tetralin as an internal standard. The quenched reaction solutions were evaporated to dryness. The crude product was fractionated by preparative SEC to give a PEGMA/HEMA (140/60) random copolymer. In a $50 \mathrm{~mL}$ roundbottomed flask filled with argon, the PEGMA/HEMA (140/60) random copolymer (HEMA unit = $0.26 \mathrm{mmol}, 300 \mathrm{mg}$ ) was placed. Then, $\mathrm{CH}_{2} \mathrm{Cl}_{2}(30 \mathrm{~mL}), 3,5$-bis(trifluoromethyl)phenyl isocyanate $(1.2 \mathrm{mmol}, 0.2 \mathrm{~mL})$, and dibutyltin dilaurate $(0.043 \mathrm{mmol}, 0.026 \mathrm{~mL})$ were added sequentially in that order into the flask at $0{ }^{\circ} \mathrm{C}$ under argon. The flask was placed in an oil bath kept at $35{ }^{\circ} \mathrm{C}$ for $12 \mathrm{~h}$. Then, the reaction was quenched by adding ethanol $(10 \mathrm{~mL})$ and the mixture was evaporated to dryness. The quantitative consumption of the hydroxyl groups in the crude product was confirmed by ${ }^{1} \mathrm{H}$ NMR analysis. The crude product was further fractionated by preparative SEC to give P10. SEC (DMF, PMMA std.): $M_{\mathrm{n}}=72,000 \mathrm{~g} / \mathrm{mol} ; M_{\mathrm{w}} / M_{\mathrm{n}}=1.17 . \quad d n / d c(\mathrm{DMF})=0.042 . \quad$ SEC-MALLS (DMF, $0.01 \mathrm{M} \mathrm{LiBr}$ ): $M_{\mathrm{w}}=108,000 \mathrm{~g} / \mathrm{mol} .{ }^{1} \mathrm{H}$ NMR [500 MHz, acetone- $d_{6}, 25{ }^{\circ} \mathrm{C}, \delta=2.05$ $\left(\mathrm{CD}_{2} \mathrm{HCOCD}\right.$ ) ]: $\delta$ 9.4-9.2 (-CONHC$\left.{ }_{6} \mathrm{H}_{4}\left(\mathrm{CF}_{3}\right)_{2}\right)$, 8.3-8.2 (aromatic), 7.7-7.5 (aromatic), 7.4-7.2 (OCOCHPhCH $2_{2}^{-}$), 4.5-4.4 (- $\left.\mathrm{COOCH}_{2} \underline{\mathrm{H}}_{2} \mathrm{OCONH}-\right)$, 4.4-4.2 (- $\left.\mathrm{COOCH}_{2} \mathrm{CH}_{2} \mathrm{OCONH}-\right)$, 4.2-4.0 ($\left.\mathrm{COOC}_{2} \mathrm{CH}_{2} \mathrm{O}-\right), 3.8-3.4 \quad\left(-\mathrm{OCH}_{2} \underline{\mathrm{CH}}_{2} \mathrm{O}-\right), 3.3 \quad\left(-\mathrm{OCH}_{3}\right), 2.2-1.5 \quad\left(-\mathrm{C}_{2} \mathrm{C}_{(}\left(\mathrm{CH}_{3}\right)-\right), 1.3-0.8 \quad$ ($\left.\mathrm{CH}_{2} \mathrm{C}\left(\mathrm{C}_{3}\right)^{-}\right)$ppm; $M_{\mathrm{n}}(\mathrm{NMR})=72,000 \mathrm{~g} / \mathrm{mol}$.

PEGMA/BPUMA (180/20) block copolymer (P12). For PPEGMA-Cl macroinitiator, $\mathrm{RuCp} * \mathrm{Cl}\left(\mathrm{PPh}_{3}\right)_{2}(0.0050 \mathrm{mmol}, 4.0 \mathrm{mg})$ was placed in a $30 \mathrm{~mL}$ glass tube. Then PEGMA (7.5 mmol, $3.3 \mathrm{~mL})$, ethanol $(6.4 \mathrm{~mL})$, tetralin $(0.2 \mathrm{~mL})$, a $500 \mathrm{mM}$ ethanol solution of 4DMAB (4DMAB $=0.1$ mmol, $0.2 \mathrm{~mL})$, and a $32 \mathrm{mM}$ ethanol solution of ECPA $(0.025 \mathrm{mmol}, 0.78 \mathrm{~mL})$ were added sequentially in that order into the tube at $25^{\circ} \mathrm{C}$ under argon (The total volume: $10.9 \mathrm{~mL}$ ). The glass tube was placed in an oil bath kept at $40{ }^{\circ} \mathrm{C}$. After $9 \mathrm{~h}$, the reaction was terminated by cooling the solution to $-78{ }^{\circ} \mathrm{C}$ (conversion $=53 \%$ : determined by ${ }^{1} \mathrm{H}$ NMR with tetralin as an internal standard). The quenched reaction solutions were evaporated to dryness. The crude product was fractionated by preparative SEC to give PPEGMA-Cl. SEC (DMF, PMMA std.): $M_{\mathrm{n}}=63400 \mathrm{~g} / \mathrm{mol} ; M_{\mathrm{w}} / M_{\mathrm{n}}=$ 
1.19. $\quad M_{\mathrm{n}}\left({ }^{1} \mathrm{H} \mathrm{NMR}\right)=73000 \mathrm{~g} / \mathrm{mol}$. Then, block copolymerization of BPUMA was conducted with PPEGMA-Cl: PPEGMA-Cl $(\mathrm{Cl}=0.015 \mathrm{mmol}, 1100 \mathrm{mg})$ and $\mathrm{RuCp} * \mathrm{Cl}\left(\mathrm{PPh}_{3}\right)_{2}(0.003 \mathrm{mmol}$, $2.4 \mathrm{mg}$ ) were placed in a $30 \mathrm{~mL}$ glass tube. Then a $313 \mathrm{mM}$ ethanol solution of BPUMA (BPUMA $=0.375 \mathrm{mmol}, 1.2 \mathrm{~mL})$, ethanol $(4.5 \mathrm{~mL})$, tetralin $(0.2 \mathrm{~mL})$, and a $500 \mathrm{mM}$ ethanol solution of 4DMAB (4-DMAB $=0.06 \mathrm{mmol}, 0.12 \mathrm{~mL}$ ) were added sequentially in that order into the tube at 25 ${ }^{\circ} \mathrm{C}$ under argon (The total volume: $7.1 \mathrm{~mL}$ ). The glass tube was placed in an oil bath kept at $40{ }^{\circ} \mathrm{C}$. After $5 \mathrm{~h}$, the reaction was terminated by cooling the solution to $-78{ }^{\circ} \mathrm{C}$ (conversion $=56 \%$ : determined by ${ }^{1} \mathrm{H}$ NMR with tetralin as an internal standard). The quenched solutions were evaporated to dryness. The crude product was fractionated by preparative SEC to give P12. SEC (DMF, PMMA std.): $M_{\mathrm{n}}=48,700 \mathrm{~g} / \mathrm{mol} ; M_{\mathrm{w}} / M_{\mathrm{n}}=1.37 . \quad d n / d c(\mathrm{DMF})=0.052$. SEC-MALLS (DMF, $0.01 \mathrm{M} \mathrm{LiBr}$ ): $M_{\mathrm{w}}=116,000 \mathrm{~g} / \mathrm{mol} .{ }^{1} \mathrm{H}$ NMR [500 MHz, acetone- $d_{6}, 25{ }^{\circ} \mathrm{C}, \delta=2.05$ $\left.\left(\mathrm{CD}_{2} \mathrm{HCOCD} 3\right)\right]: \delta 9.1-8.7$ (-NHCONHC$\left.{ }_{6} \mathrm{H}_{4}\left(\mathrm{CF}_{3}\right)_{2}\right), 8.2-8.0$ (aromatic), 7.5-7.4 (aromatic), 7.4-7.2 (-OCOCHPhCH $\left.2_{2}^{-}\right)$, 6.5-6.3 (- $\left.\mathrm{CH}_{2} \underline{\mathrm{NHCO}}^{-}\right)$, 4.3-4.0 (- $\left.\mathrm{COOC}_{2} \mathrm{CH}_{2}-\right), 3.8-3.4\left(-\mathrm{OC}_{2} \underline{\mathrm{CH}}_{2} \mathrm{O}-\right.$, $\left.\mathrm{COOCH}_{2} \mathrm{CH}_{2} \mathrm{NH}-\right)$, 3.4-3.3 (-OCH 3$), 2.2-1.5\left(-\mathrm{CH}_{2} \mathrm{C}\left(\mathrm{CH}_{3}\right)^{-}\right), 1.3-0.8\left(-\mathrm{CH}_{2} \mathrm{C}\left(\mathrm{CH}_{3}\right)^{-}\right)$ppm; $M_{\mathrm{n}}$ $(\mathrm{NMR})=77,300 \mathrm{~g} / \mathrm{mol}$. 


\section{Supporting Data}

(a)
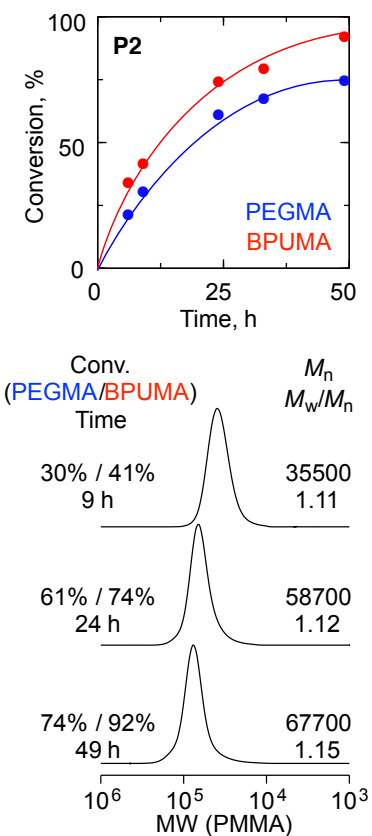

(e)
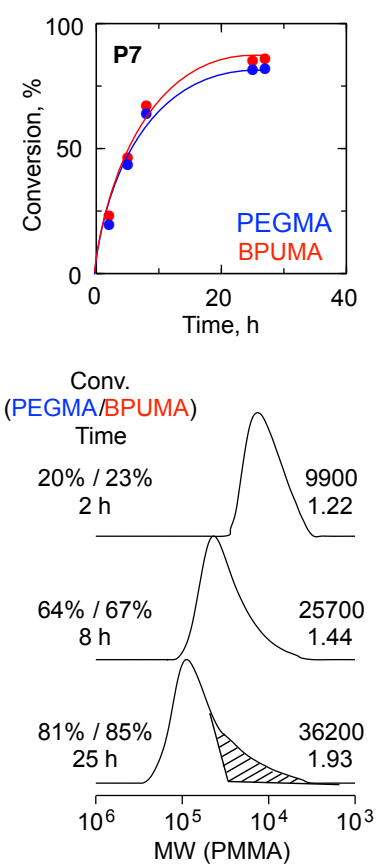

(b)
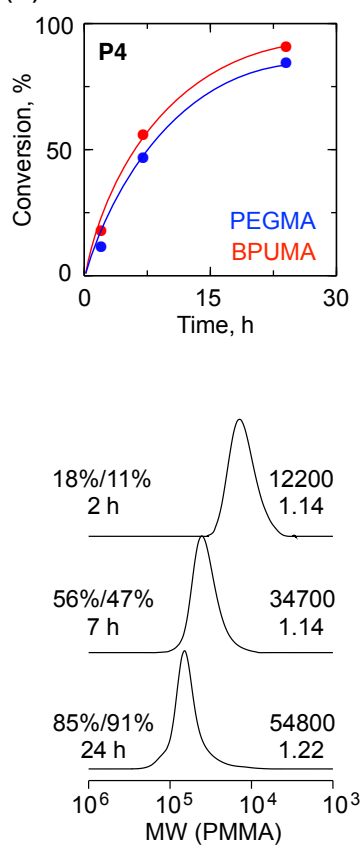

(f)
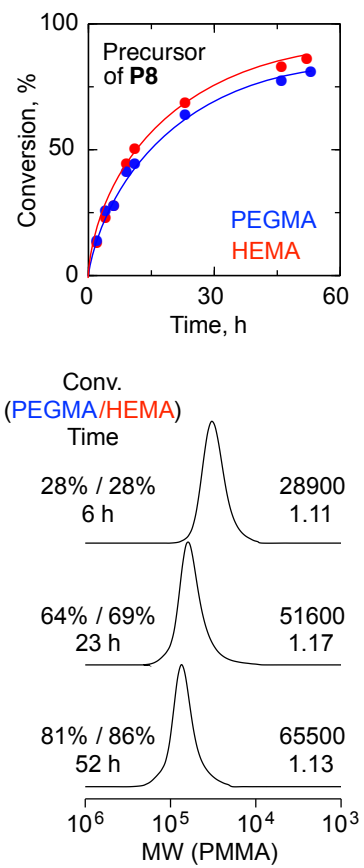

(c)

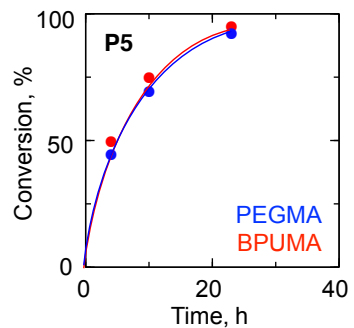

(d)
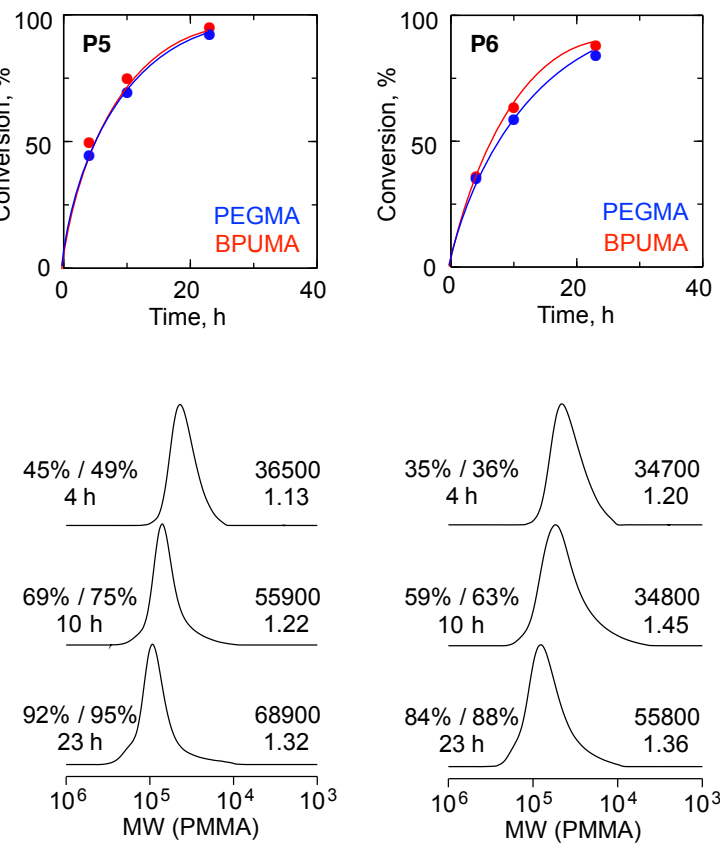

(g)

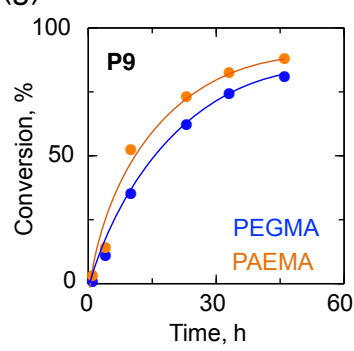

(h)
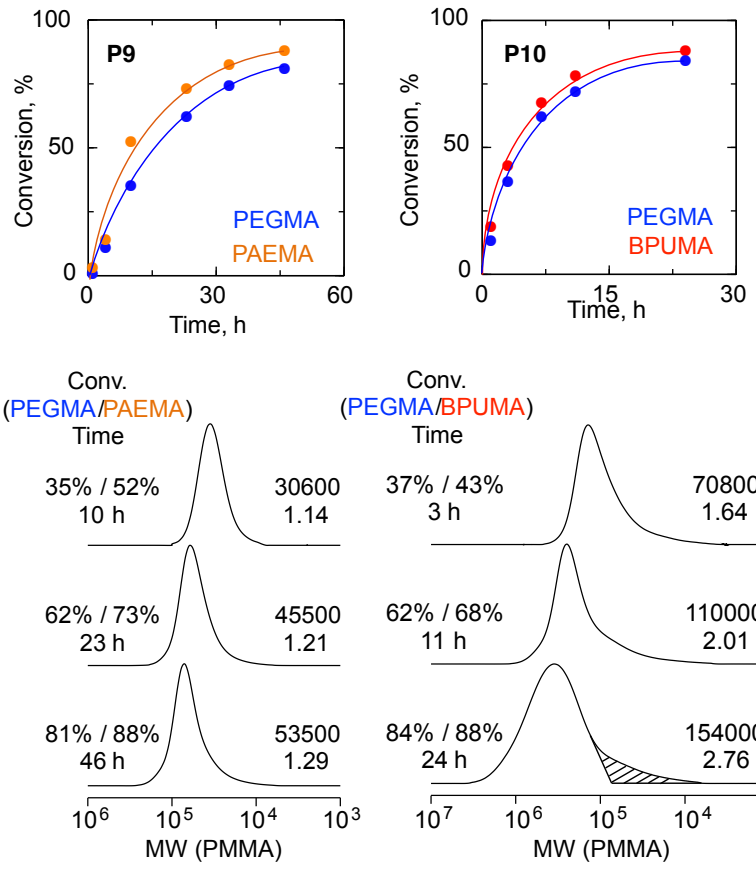

Conv.

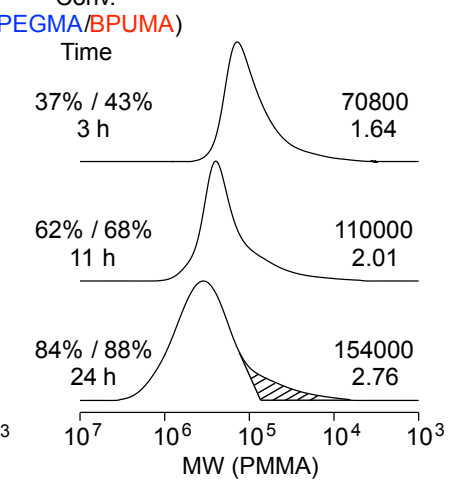

Figure S1. Ruthenium-catalyzed living radical copolymerization of PEGMA and RMA (a-e, h: BPUMA, f: HEMA, g: PAEMA) for PEGMA/BPUMA (a: 190/10, P2; b: 160/40, P4; c: 140/60, P5; d: 120/80, P6; e: 100/100, P7; h: 420/180, P10), PEGMA/HEMA (f: 140/60, a precursor of P8), and PEGMA/PAEMA (g: 140/60, P9) random copolymers. The shaded portion for (e) and (h): removed by preparative SEC. 

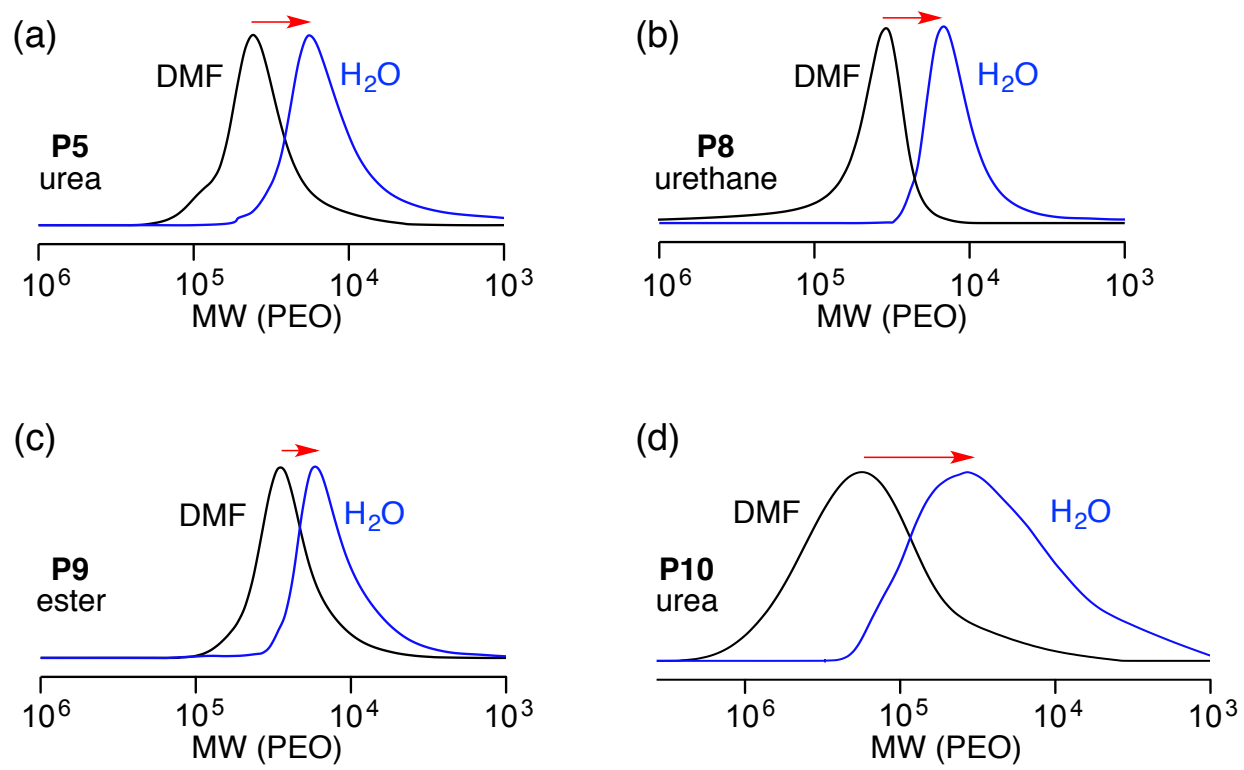

Figure S2. SEC curves of (a) P5, (b) P8, (c) P9, and (d) P10 in DMF and $\mathrm{H}_{2} \mathrm{O}$.
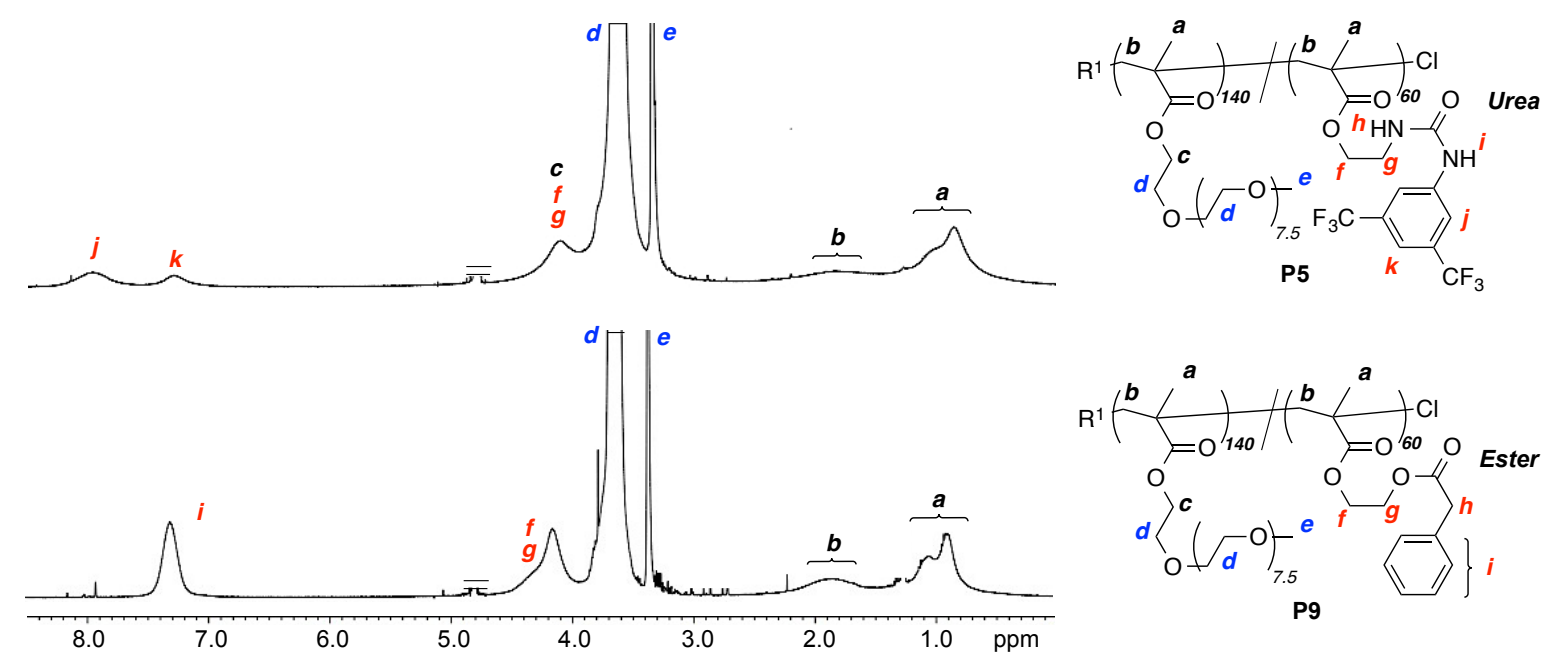

Figure S3. ${ }^{1} \mathrm{H}$ NMR of $\mathbf{P 5}$ and $\mathbf{P 9}$ in $\mathrm{D}_{2} \mathrm{O}$ at $25{ }^{\circ} \mathrm{C}$. 


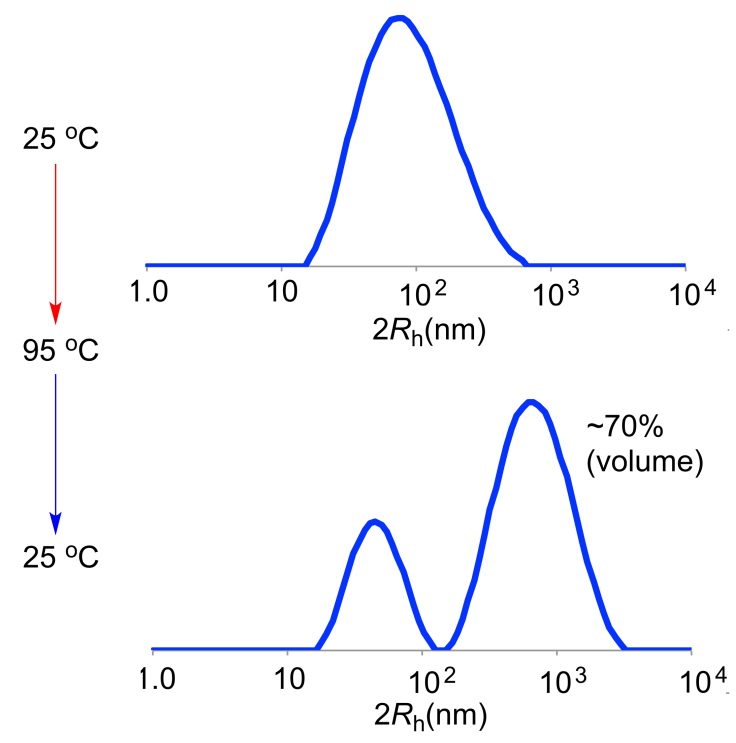

Figure S4. DLS intensity distribution of P12 before and after LCST-type phase separation (at 95 ${ }^{\circ} \mathrm{C}$ ) in water at $25{ }^{\circ} \mathrm{C}:[$ polymer] $=10 \mathrm{mg} / \mathrm{mL}$.

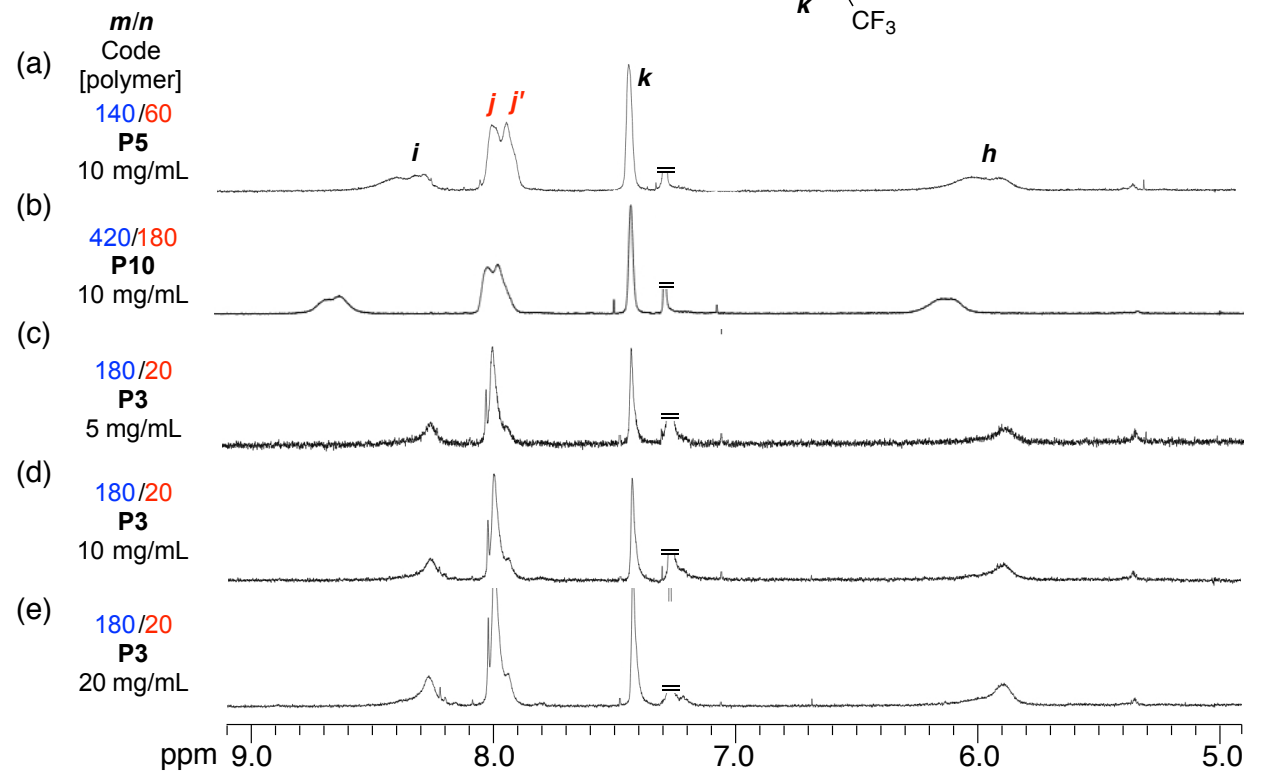

Figure S5. ${ }^{1} \mathrm{H}$ NMR spectra of (a) P5, (b) P10, and (c-e) $\mathbf{P 3}$ in $\mathrm{CDCl}_{3}$ at $25{ }^{\circ} \mathrm{C}$ : [polymer] = (c) 5 , (a, b, d) 10, and (e) $20 \mathrm{mg} / \mathrm{mL}$. 
(a) BPUMA

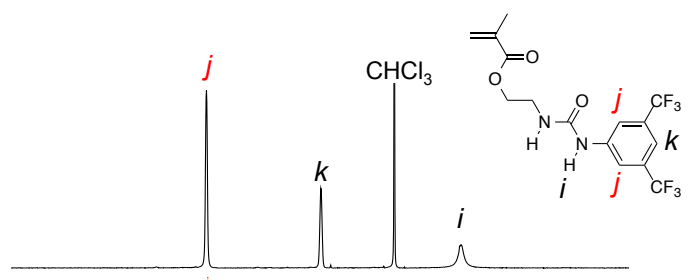

(b) BPUMA+MMA

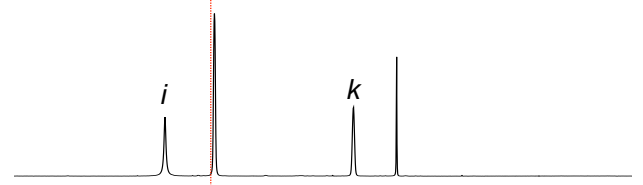

(d) BPUMA+PEG

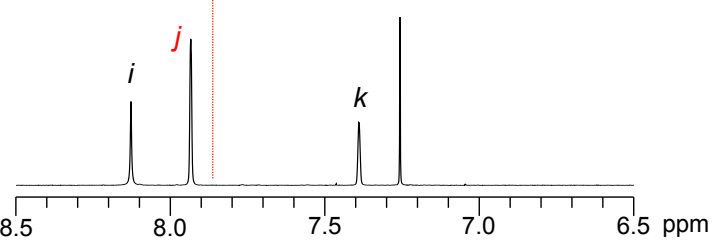

Figure S6. $\quad{ }^{1} \mathrm{H}$ NMR spectra of (a) BPUMA (20 mM) alone or in the presence of (b) MMA (300 $\mathrm{mM}$ ) and (c) poly(ethylene oxide) (PEO: $M_{\mathrm{n}}=2000,20 \mathrm{mM}$ ) in $\mathrm{CDCl}_{3}$ at $25{ }^{\circ} \mathrm{C}$.

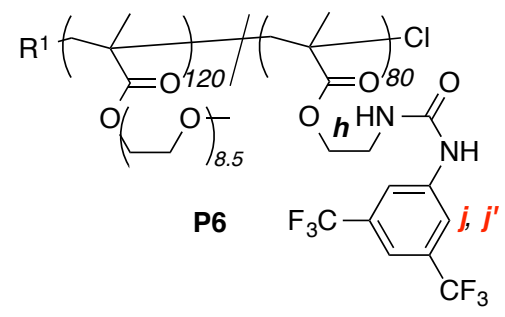

(a)

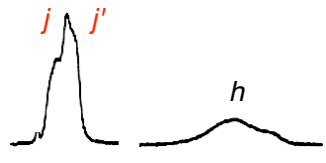

(b)

(c)
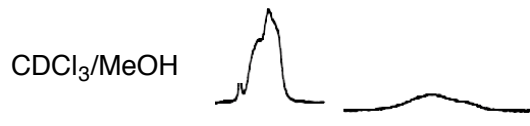

(d)
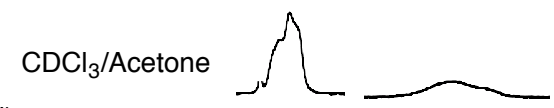
$\mathrm{CDCl}_{3} /$ Acetic Acid

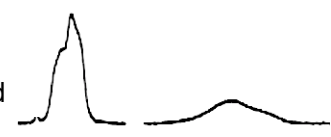

(e)

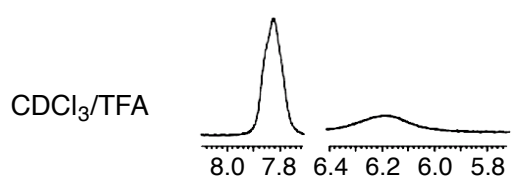

(f)

[Acetic Acid]/[urea]

0

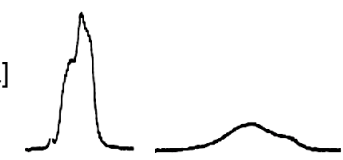

(g)

10

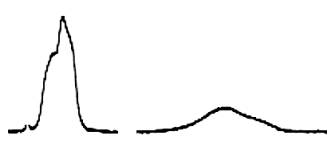

(h)

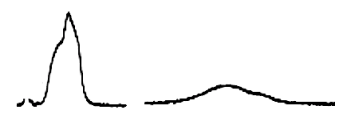

(i)

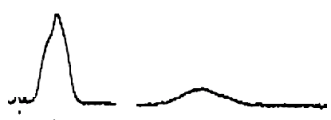

(j)

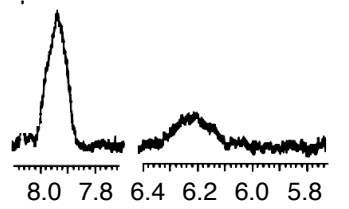

Figure S7. $\quad{ }^{1} \mathrm{H}$ NMR spectra of $\mathbf{P 6}$ in $\mathrm{CDCl}_{3}$ in the presence of polar compounds (b: $\mathrm{MeOH}$; c: acetone; d: acetic acid; e: TFA) at $25^{\circ} \mathrm{C}$ : [urea]/[polar compounds] $=0$ (a), 10 (b-e,g), 100 (h), 500 (i), and 1000 (j). 


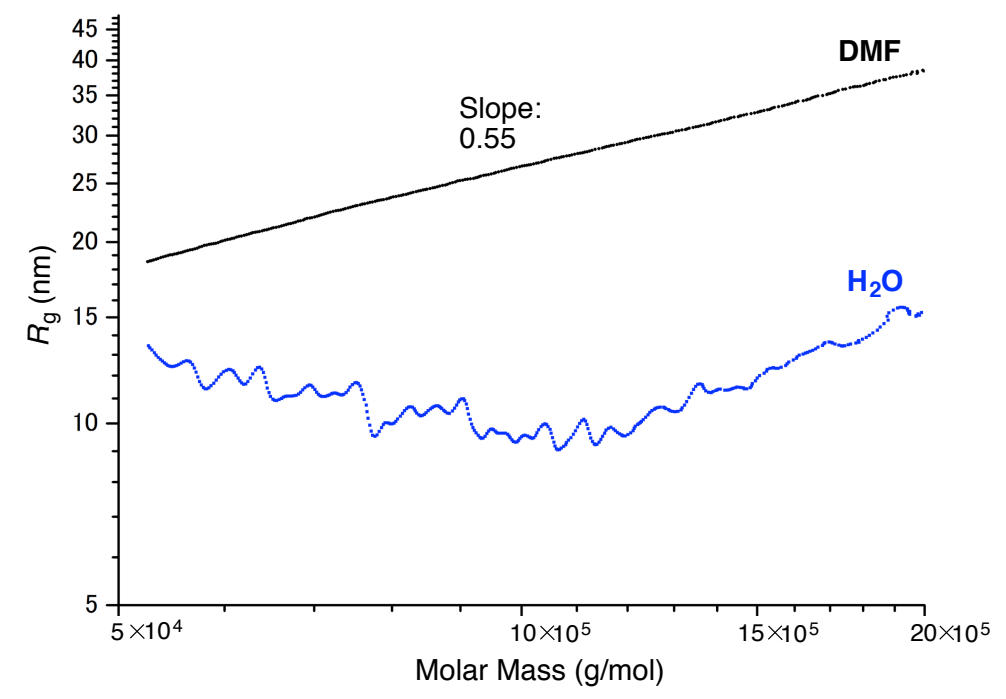

Figure S8. Plots of $R_{\mathrm{g}}$ for P10 as a function of molar mass determined by SEC-MALLS in DMF or $\mathrm{H}_{2} \mathrm{O}$. 
(a) P5 in $\mathrm{H}_{2} \mathrm{O}$

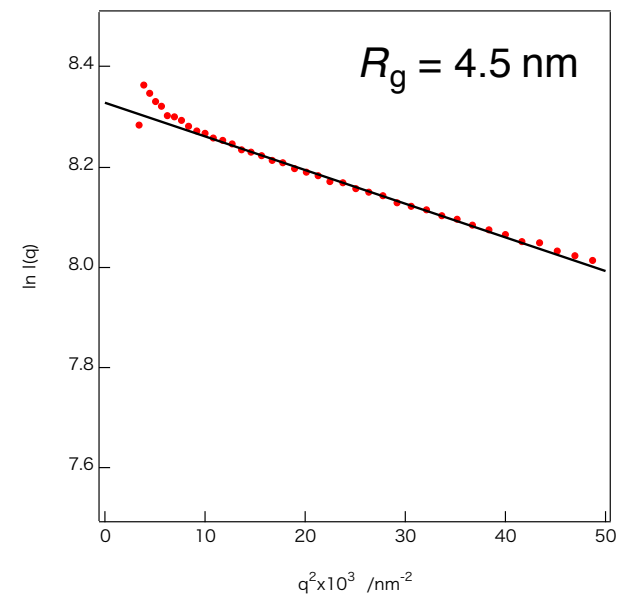

(c) P9 in $\mathrm{H}_{2} \mathrm{O}$

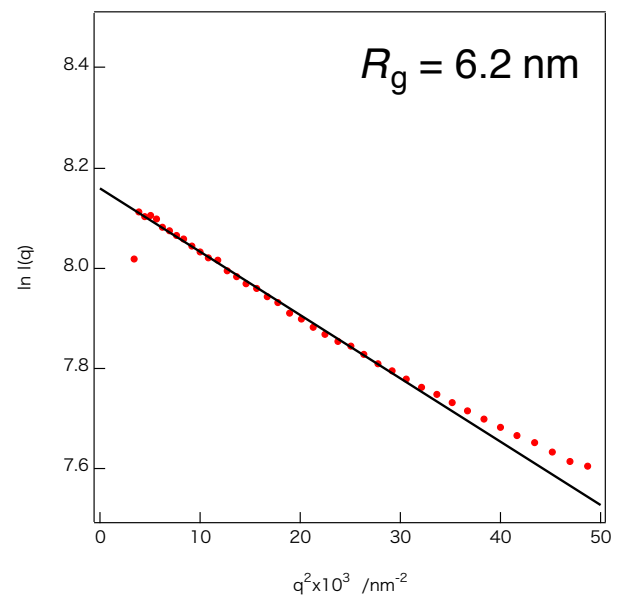

(b) P5 in DMF

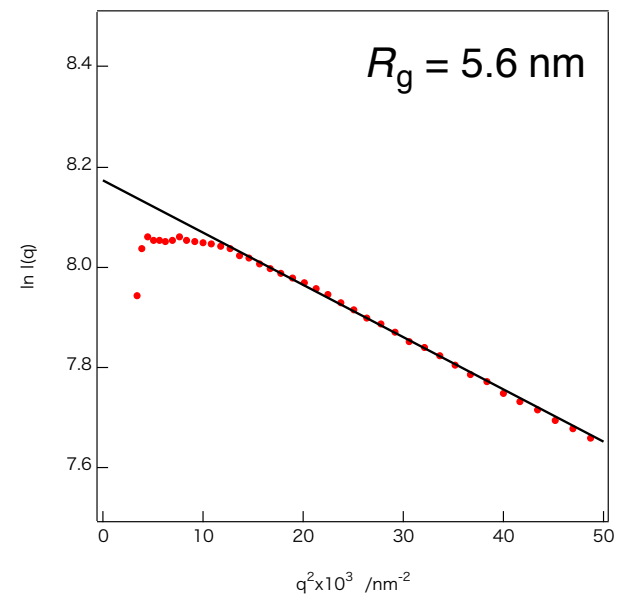

(d) P9 in DMF

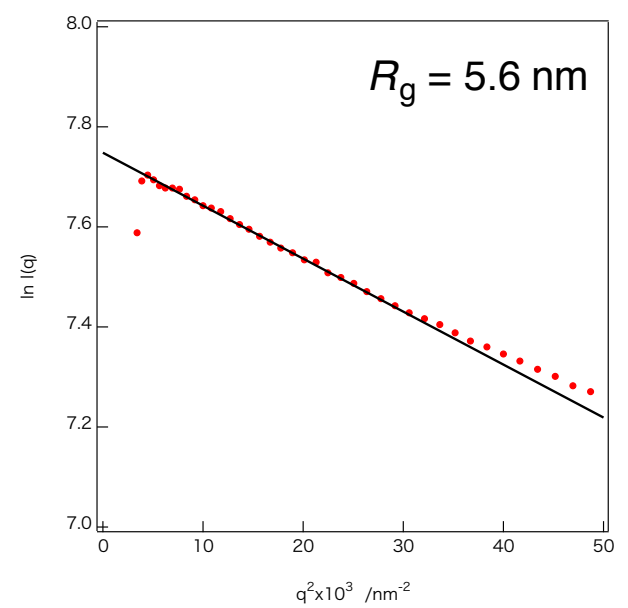

Figure S9. Guinier plots for the SAXS profiles of $(a, b)$ P5 and (c, d) P9 in (a, c) water or (b, d) DMF. 